\title{
Selected geosites and geotourist objects in Colca Canyon and its vicinity (Southern Peru)
}

Wybrane geotopy i obiekty geoturystyczne kanionu Colca i jego otoczenia (południowe Peru)

\section{Barbara Radwanek-Bąk}

Państwowy Instytut Geologiczny, Oddziat Karpacki Kraków e-mail: barbara.radwanek-bak@pgi.gov.pl

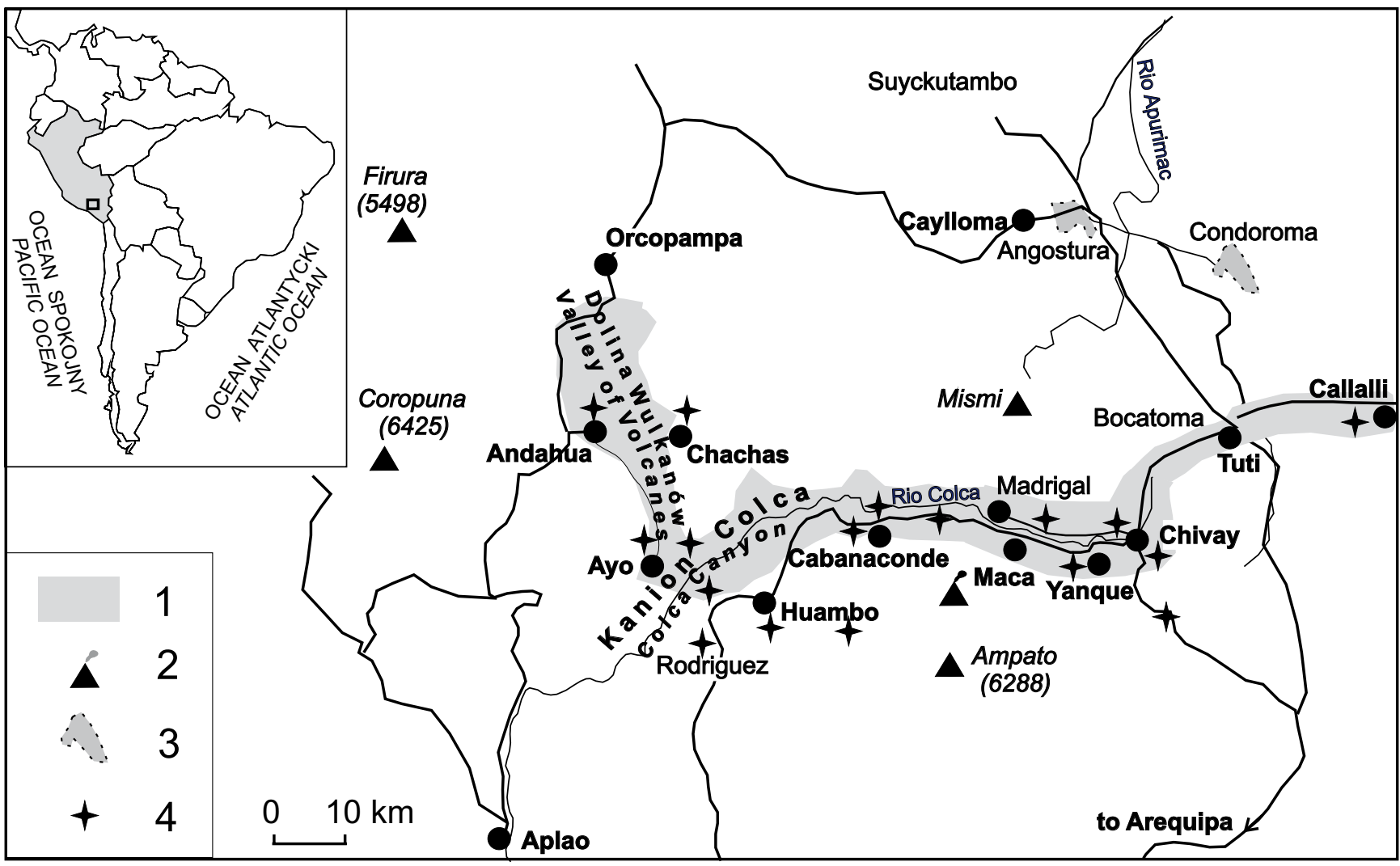

Fig. 1. Canyon Colca region. 1 - national park in project, 2 -stratovolcano, 3 -water reservoir, 4 -geotouristic phenomenon $\bullet$ Mapa okolic Kanionu Colca. 1 - projektowany park narodowy, 2 - stratowulkan, 3 - jezioro zaporowe, 4 - atrakcja geoturystyczna

Abstract: This article presents several selected geotourism attractions and phenomena located in the Rio Colca Valley and its surroundings. The basis for the assessment of geotourist potential of the studied region was an inventory of geotourist attractions. Then a primary evaluation of geotourist sites was performed based on the following valorisation criteria developed by the author: educational-cognitive assets, landscape-visual assets, architecture-cultural assets and recreational-resting assets. The reconnaissance study shows the richness of bio- and geodiversity of the region as well as its unique landscape values, which have to bee protected. So the main goal of further activity has to be focused to give the scientific base for future creation here The Colca Canyon National Park.

Key words: Canyon Colca, geotourist attraction, inanimated phenomena, nature protection

Treść: Artykut przedstawia kilka wybranych atrakcji i zjawisk geoturystycznych, znajdujacych się $w$ dolinie rzeki Colca $i$ w jej otoczeniu. Podstawa oceny potencjatu geoturystycznego $w$ tym rejonie byta inwentaryzacja atrakcji geoturystycznych. Nastęnie wykonano wstępna ocene oparta na nastęujacyh kryteriach: edukacyjno-poznawczym, krajobrazowo-wizualnym, architekturowo-kulturowym i rekreacyjno-wypoczynkowym. Wstępne badania wykazaty bogactwo bio- i georóżnorodności $w$ regionie oraz wyjatkowa wartość krajobrazowa, które to elementy wymagaja ochrony. Głównym zadaniem na przyszłość powinno być stworzenie naukowych podstaw tworzenia Parku Narodowego Kanionu Colca.

Slowa kluczowe: Kanion Colca, atrakcje geoturystyczne, zjawiska przyrody nieożywionej, ochrona przyrody

\section{Introduction}

Under this framework, the Colca Valley and its fragment which forms the deepest canyon of the Word is the region of unquestionable values. The unusual geodiversity, extraordinary landscape as well as the fame and interest associated with the canyon make this region particularly outstanding. The region is even more appealing as active geological processes can be observed here easily. Many tourists are also at- 


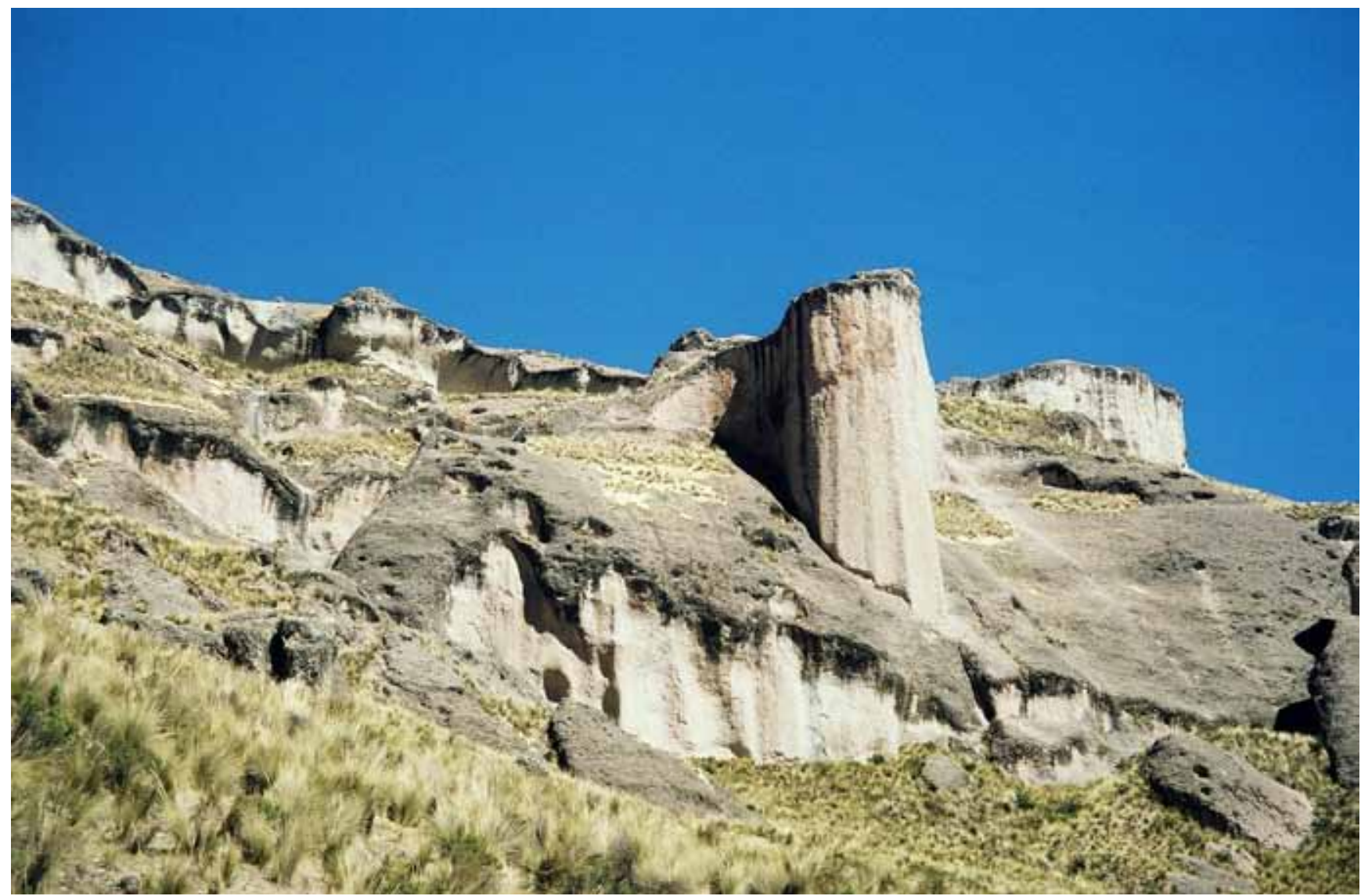

Fig. 2. Pillar-forming ignimbrite near Callalli village, phot. B. Radwanek-Bąk • Wychodnie ignimbrytów, tworzących charakterystyczne kolumny k. Callali, fot. B. Radwanek-Bąk

tracted by a possibility of watching here the winged rulers of this region - the condors, while other visitors - by an option for checking their physical fitness during expeditions to the canyon floor.

Likewise the biodiversity refers to abundant assortment of animate nature, the term geodiversity denotes variability and differentiation of abiotic elements (Nieto, 2001, Gray, 2004, Kozłowski, 2004, Kot, 2004, Panizza, Piacente, 2009).

Thus, geodiversity comprises diversified geological settings, rocks and soils, tectonic structures, evolution of erosional forms as well as morphological development of landforms and watercourses. What is more, it is the geodiversity which often controls the biodiversity. Both these attributes coupled with anthropogenic impact on the environment generate diversity which in turn adds to the landscape attractiveness.

Visiwble indications of the geodiversity are geosites (geotops) - some elements of abiotic nature, which give a clear and distinct information about geological development of lithospfere and about the history of the life of on earth (Serrano, Ruiz-Fano, 2009). Geosites are usually divided into three main groups: geological exposures (representing various geologic branches), geomorphosites, and hydrogeological geotopes (Brushi, Cendrero, 2009). All of them have to characterize significant scientific and educational values, as well as some other additional features like: scenic, cultural, aesthetic, socio-economic. Many geosites are used to be the geotourist attractions. By definition (Słomka, KicińskaŚwiderska, 2004), the geotourist attractions are geologic objects as well as phenomena which might be of interest to visitors. However, to make them really appealing, they need to be made easily accessible and promoted. A fundamental issue in this respect is information about potential sites combined with their comprehensive characteristics, valorisation and concepts on making them accessible. A unique attribute of geotourist attractions are their sizes which, as a rule, are not confined. Thus, vast morphological landforms or hydrogeological objects as well as singular exposures or outcropping fragments, which reveal interesting geologic profiles, mineral-petrographic occurrences, small geomorphic forms, springs, caves or mining pits etc. can be geosites of equal degree of interest.

Examination of geotourist potential of the Colca Canyon and its vicinity was one of the research tasks of the exploration expeditions undertaken by scientists from the University of Science and Technology (AGH) and other Polish research institutions in 2006 and 2008.

The author is grateful to the expedition organizers for making her participation in the inter-disciplinary team possible as well as for enabling her own studies.

\section{Methods of the study}

The basis for the assessment of geotourist potential of the studied region was an inventory of geotourist attractions. The inventory was based on different source materials including archive documentaries, which were made available by the local authorities. Moreover, representatives of local authori- 


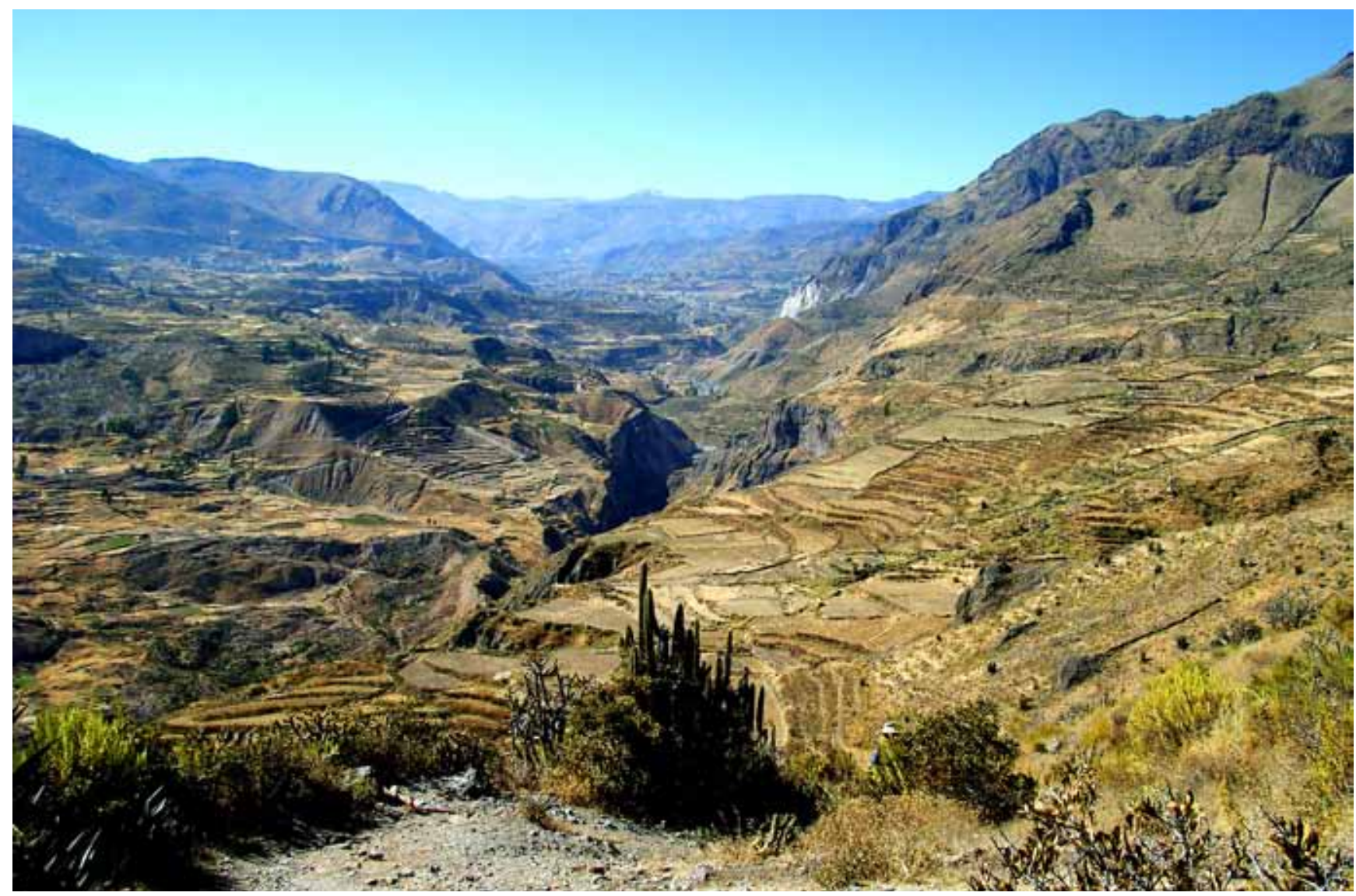

Fig. 3. Rio Colca Valley near Chivay, phot. B. Radwanek-Bąk • Dolina Rio Colca w okolicach Chivay, fot. B. Radwanek-Bąk

ties, tourist offices and inhabitants were interviewed on potential attractive geosites. The data collected this way were then verified in the field.

A primary evaluation of geotourist sites was performed based on the following valorisation criteria developed by the author (Radwanek-Bąk, 2008):

- scientific-cognitive assets

- landscape-visual assets

- architecture-cultural assets

- recreational-resting assets.

- accessibility

The first out of the above listed is the crucial criterion to accept a given object as the geotop.

The remaining criteria are additional attributes, which can but need not to co-occur in all geotourist objects or phenomena. Nevertheless, at least one of these additional criteria must be satisfied in order to consider the given object the geotourist attraction rather than to treat the object as important from strictly geological viewpoint.

During the field work, which lasted almost a month, the information on several tens of objects and phenomena that might be potential geotourist attractions, was verified.

The area of interest comprised the Colca Valley starting form the settlement of Callalli to Huambo region as well as the Valley of Volcanoes (Fig. 1). The latter runs crosswise to the Colca Valley axis. The Mamacocha and Ayo rivers, draining the Valley of the Volcano floor, join the Colca River in its canyon section.

\section{The Colca Valley}

The Colca River starts high in the Andes on the slopes of Yanasalla Mt. (4886 $\mathrm{m}$ a.s.1.) which perches above the high plateau, the latter being the southern part of the Altiplano. In its upper course the river flows in uninhabited regions and cuts young deposits formed from weathered volcanic rocks, mainly tuffs andesite lavas. The latter are associated with the Miocene-Pliocene volcanisms. The Tacaza Group includes several formations comprising older Miocene volcanic rocks (Paulo, 2008). Wonderfully developed ignimbrite formations (of tuff variety) with characteristic columnar joints can be observed in the upper reaches of the Colca Valley close to Callalli (Fig. 2). Because of its thermal properties and easy processing, ignimbrite is a common dimension stone all over the Arequipa province.

Sibayo is one of the first permanent settlements in the upper reach of the valley, while Chivay, the local administrative and tourist centre, is the most important one. Between Chivay in the east and Huambao in the west, the Colca Valley is surrounded by high startovolcanoes. These are Nevado Mismi (5597 $\mathrm{m}$ a.s.1.) and Nevado Bomboya (5 $200 \mathrm{~m}$ a.s.1.) in the north, Nevado Coropuna (6 $425 \mathrm{~m}$ a.s.1.) in the distance of $0 \mathrm{~km}$ to the north-west, and Nevado Hualca-Hualca (6 $025 \mathrm{~m}$ a.s.1.), Sabancaya (5976 m a.s.1.) and Ampato (6314 m a.s.1.) in the south. Their activity that has been lasting since the Pliocene is evidenced by thick volcanic-sedimentary deposits (Fidel et al., 1997), which include andesite, dacite and dacite-andesite lavas as well as tuffs, andesite breccias and conglomerates. 


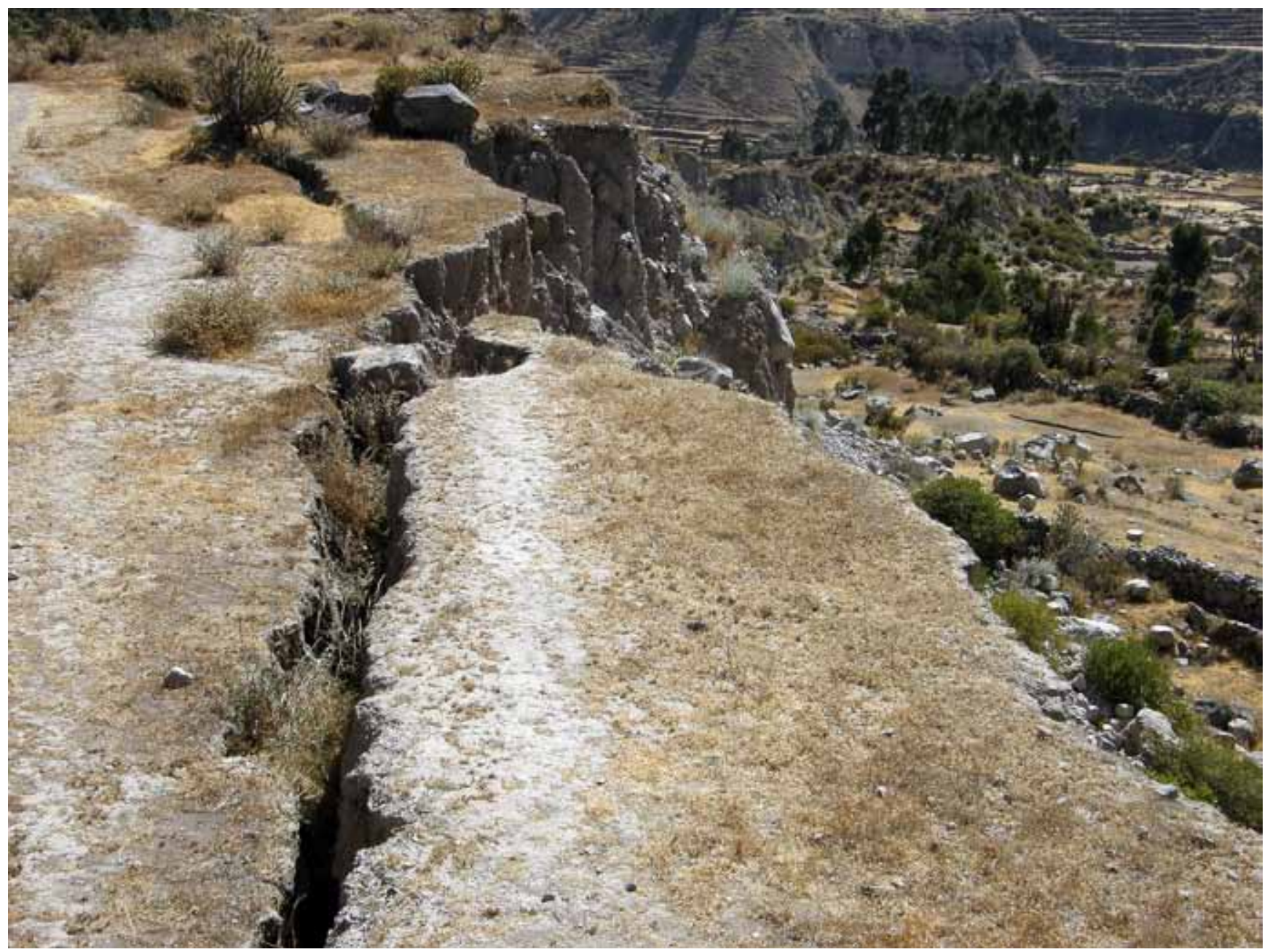

Fig. 4. Active fault zone Maca-Madrigal, phot. B. Radwanek-Bąk • Aktywna strefa uskokowa Maca-Madrigal, fot. B. Radwanek-Bąk

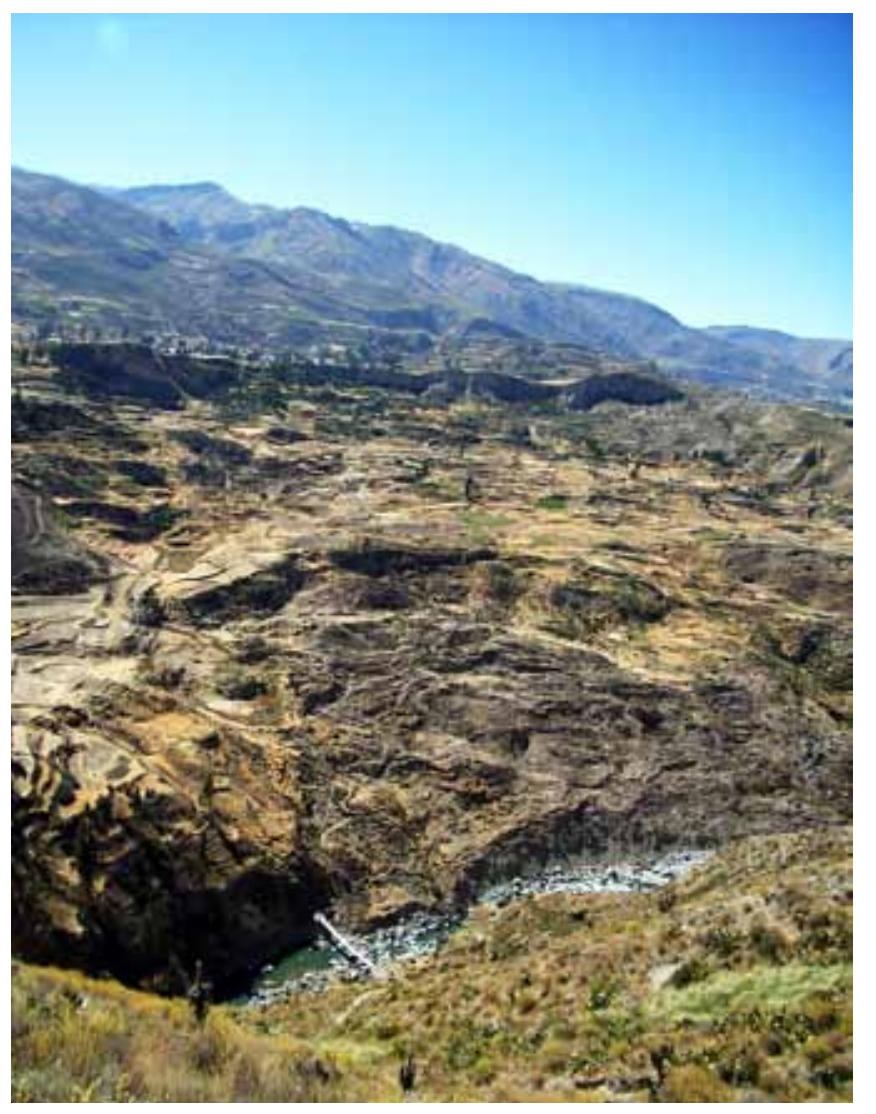

Their vary-aged complexes form the Barroso Group (Caldas, 1993). Below Chivay the character of the Colca Valley changes significantly. The river cutting its thick bedrock has formed several terrace levels, but their primary appearance has been drastically changed by human activity. Owing to favourable climatic conditions and fertile soils developed on volcanic bedrock this part of the valley has been inhabited and farmed since the pre-Inca times (Wernke, 2003).

The discussed section of the valley is believed to be a geotourist attraction which provides opportunities for learning the main geological setting and rock varieties, and even more, for tracing geomorphology that has been modified due anthropogenic impact lasting for centuries (Fig. 3). The viewpoints enable thorough observations. In the valley there are also other, yet smaller, geotourist attractions, including the sites where particular geological phenomena can be observed:

- Maca-Madrigal fault zone (Fig. 4);

- active landslide with some ponds near Madrigal city (Fig. 5).

Apart from strictly educational value these site have highly appreciated landscape.

A different type of geotourist attractions is associated with thermal waters occurring in the discussed area. These waters

Fig. 5. An example of active landslide on the slopes of Rio Colca Valley near Lari, phot. B. Radwanek-Bąk - Przykład rozległego, aktywnego osuwiska obejmującego stoki doliny Colca w okolicach Lari, fot. B. Radwanek-Bąk 


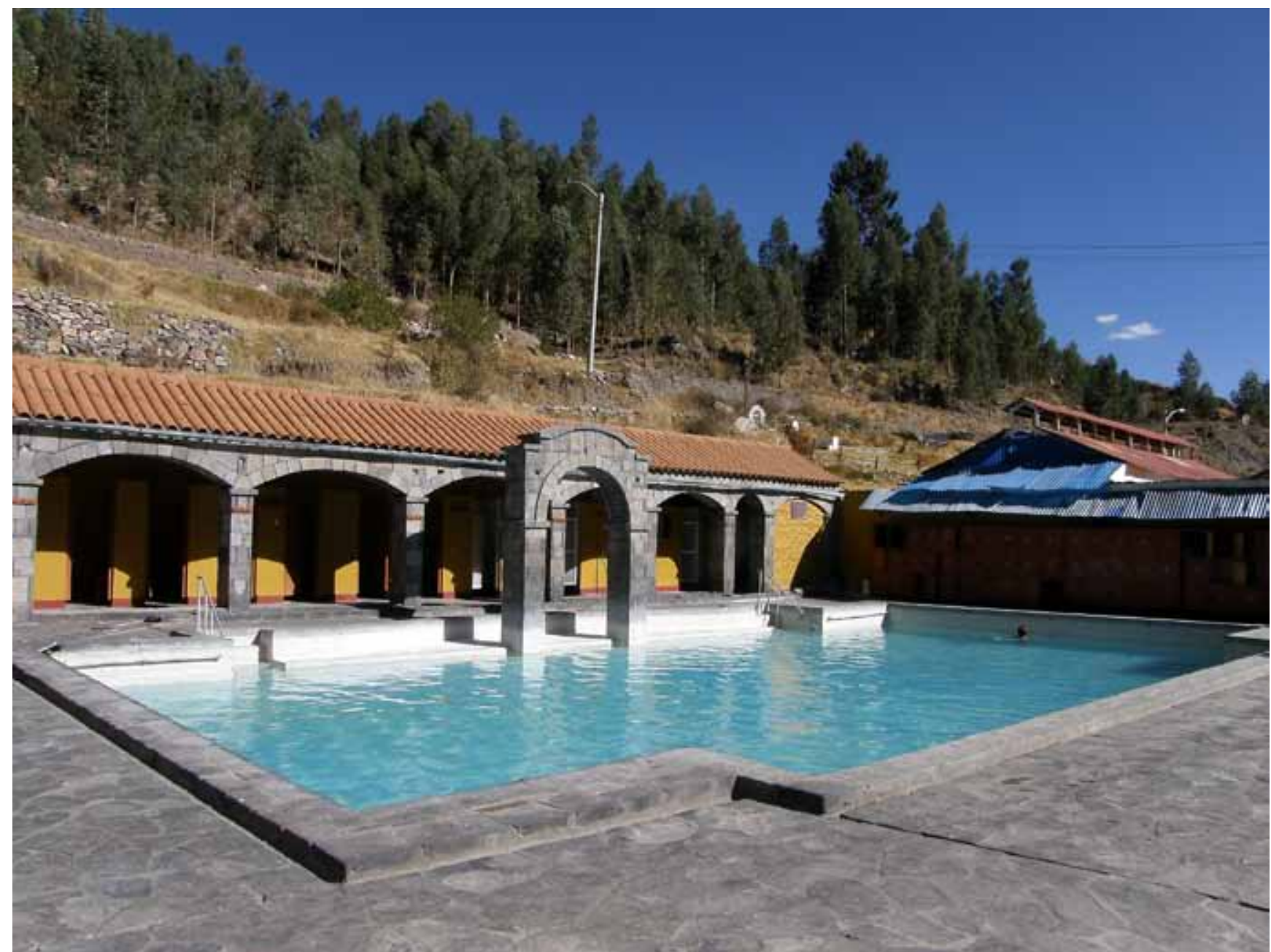

Fig. 6. La Calera - a recreation complex of thermal water swimming pools near Chivay, phot. B. Radwanek-Bak $\bullet$ La Calera - termalny kompleks rekreacyjny koło Chivay, fot. B. Radwanek-Bąk)

are plentiful but of limited discharges, so they are operated from a few intakes only. The most important are La Calera in Chivay (Fig. 6) and springs in Yanque where swimming pools have been built.

Diatomites in Maca (Fig. 7) are mineralogic-petrographic geotourist attractions. These organogenic rocks comprising skeletons of diatoms are good evidence of fresh water basin which had to be present here in the past. Concentration of diatoms was likely favoured by low temperature of water and by a high content of dissolved silica, which probably originated from volcanic deposits that are common here.

Numerous outcrops of lake deposits, which are often thick, substantiate the presence of fresh water bodies in this region. These lacustrine deposits are silty and finely laminated, and sometimes even obliquely laminated (Fig. 8). The liminic series comprise intercalations of coarse clastic alluvial deposits (Kalicki, Kukulak, 2008). The presence of liminic deposits is likely associated with a large eruption of Mismi volcano that took place at the turn of the Pliocene and Quaternary. The outcrops of the discussed deposits can be treated as sedimentological attractions of high educational value. Observations of these outcrops, inter-correlations and age determination can contribute to refining the geological history of the valley, and particularly to verifying the timing of the Colca Canyon Formation.

\section{The Colca Canyon in the section between Pinchollo and Canco}

The Colca Canyon starts close to Pinchollo. It is ca $120 \mathrm{~km}$ long and in its deepest spot reaches $3232 \mathrm{~m}$. The access to it is limited and tourists are allowed only to the section between Pinchollo and Canco, where the canyon depth (to the valley level) reaches ca. $1800 \mathrm{~m}$. Some trails from Pinchollo, Cabanaconde and Huambo descend to the canyon floor. It is also possible to access the canyon from the Valley of the Volcanoes and Ayo city but that descend requires a good skill. The canyon fragment down of Canco is hardly accessible, as this is the deepest part surrounded by waterless and unpopulated terrains (for example in the region of Gloriahuasi). Lack of water and the necessity of crossing long distances as well as significant height differences are the major difficulties, which potential tourists to the canyon floor will face. Other trouble might be related to steep and fragile rocks forming the canyon walls. In the region, which is the most popular among the tourists, close to Cabanaconde, the canyon walls are mainly built of thick complexes of volcanic rocks representing the above described formations of the Tacaza and Barroso groups (Fig. 9). The older sedimentary rocks of the Yura Group, from the Jurassic (Oxfordian - Kimmeridgian) to the Early 


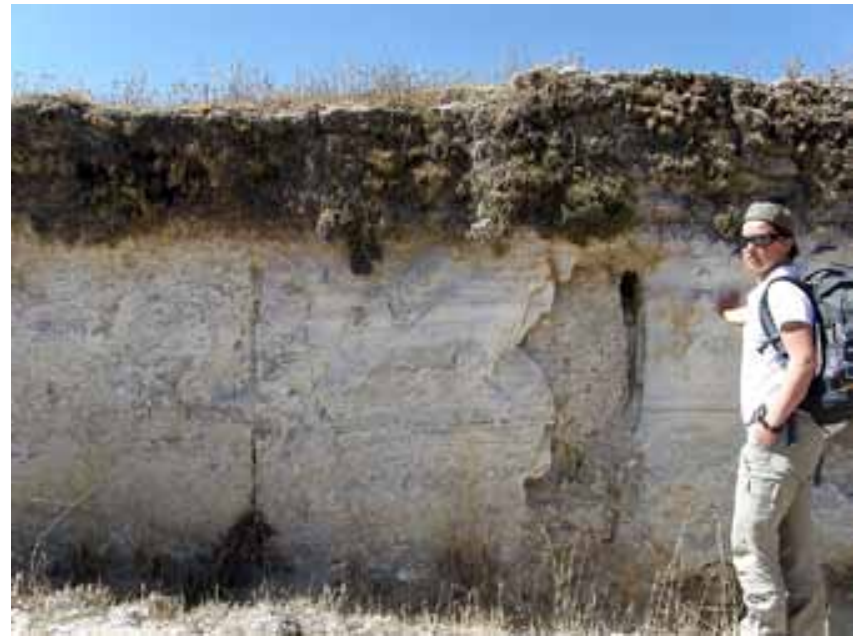

Fig. 7. Outcrop of diatomite rock in Maca, phot. B. Radwanek-Bąk - Wychodnia diatomitów w Maca, fot. B. Radwanek-Bąk

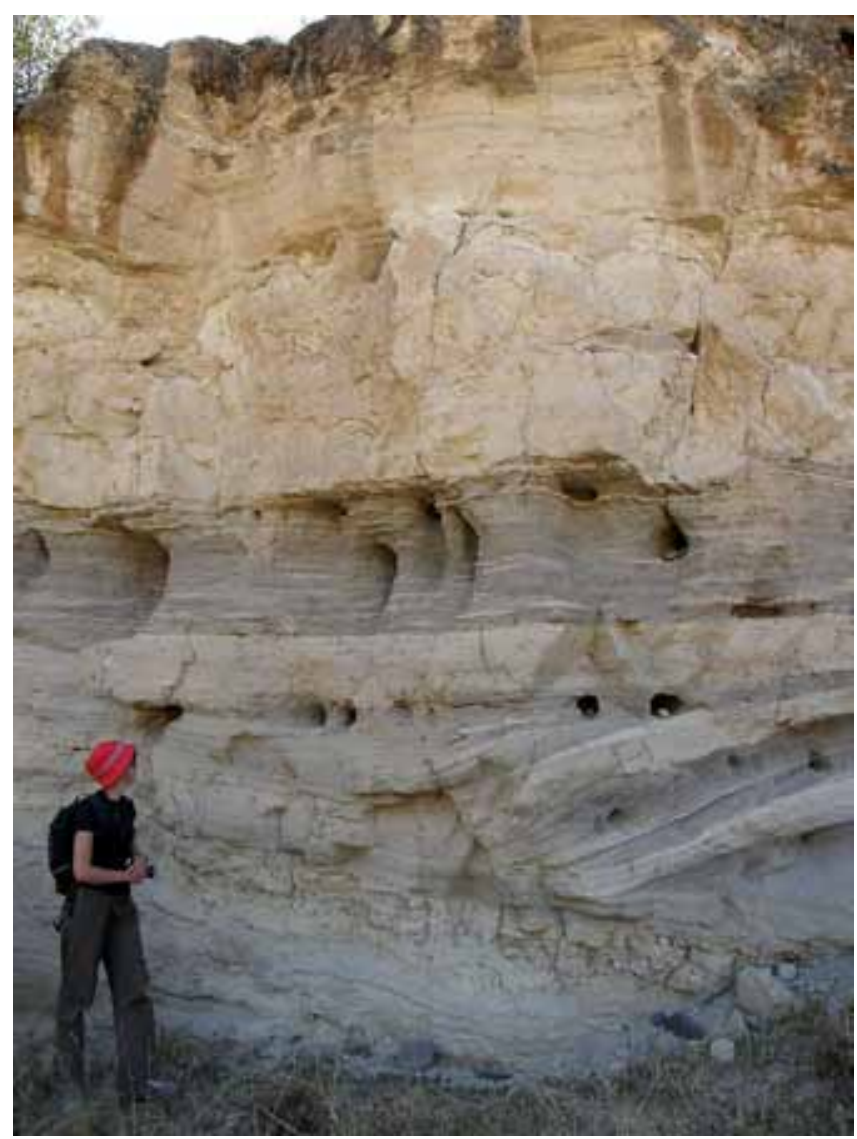

Fig. 8. Sediments of lacustrine series on the slopes of Rio Colca Valley near Coporaque, phot. B. Radwanek-Bąk • Osady serii jeziornej w zboczach dolony Colca w pobliżu Coporaque, fot. B. Radwanek-Bąk

Cretaceous (Valanginian), in age crop out in the lower and bottom parts of the Cola Canyon. In general they comprise dark-grey sandstone-shales, sometimes with lutite intercalations. The sandstones are sedimentary rock with calcareous or siliceous cement (Caldas, 1993). Between Pinchollo and Soro the rocks of the Yura Group crop out at the cayon bottom while in the region of Huambo and in the lower reach of the Mamococha tributary (which drains the Valley of the Volcanoes and flows in to the Colca River) they built the canyon walls (Fig. 10). The profiles of the canyon walls, exposures

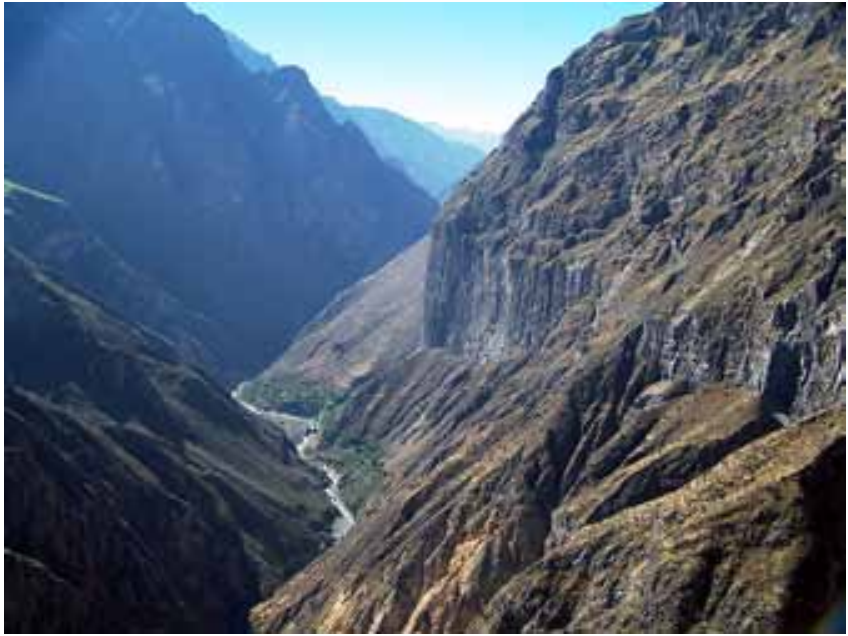

Fig. 9. Volcanic rocks of Tacaza (Miocene) and Barroso (PliocenePleistocene) groups in the Colca Canyon near Cabanaconde, phot. B. Radwanek-Bak • Skały wulkaniczne mioceńskiej grupy Tacaza i plioceńsko-plejstoceńskiej grupy Barroso budujące stoki kanionu w rejonie Cabanaconde, fot. B. Radwanek-Bąk

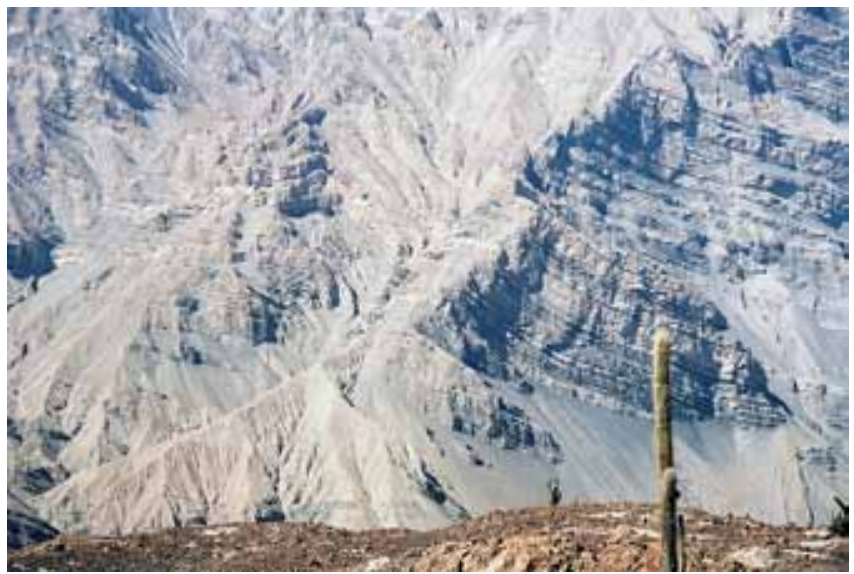

Fig. 10. Folded sedimentary strata of Yura Group (Upper JourassicLower Cretaceous) exposed in Rio Mamacocha Valley, phot. B. Radwanek-Bąk • Sfałdowane skały osadowe grupy Yura - górna jura - dolna kreda w okolicach Rio Mamacocha, fot. B. Radwanek-Bąk

of rock formations and fold structures as well as the canyon morphology are tourist attractions of outstanding educational-cognitive values and landscape-visual assets. Observations of these features can be made during trips to the canyon as well as from numerous viewpoints including Cruz del Condor. Form this most famous lookout the tourists can watch condors flying early morning out of the canyon.

\section{Valley of the Volcanoes}

The Valley of the Volcanoes, ca. $60 \mathrm{~km}$ long, is a side valley of the Colca Valley. Considering geology, the valley is a tectonic trough filled up with the Neogene tuffs overlain by the very young Pleistocene lavas of the Andahua Formation (Gałaś, Paulo, 2005). Dwarf volcanoes, which form regular cones, are numerous here (Fig. 11). According to various source documentaries they amount from at least 31 up to 85 (Krzak, 2005).

The visit to the Valley of the Volcanoes is an opportunity for observing almost real-time effects of the volcanic activity such as formation of volcanoes or lava streams. The lavas 


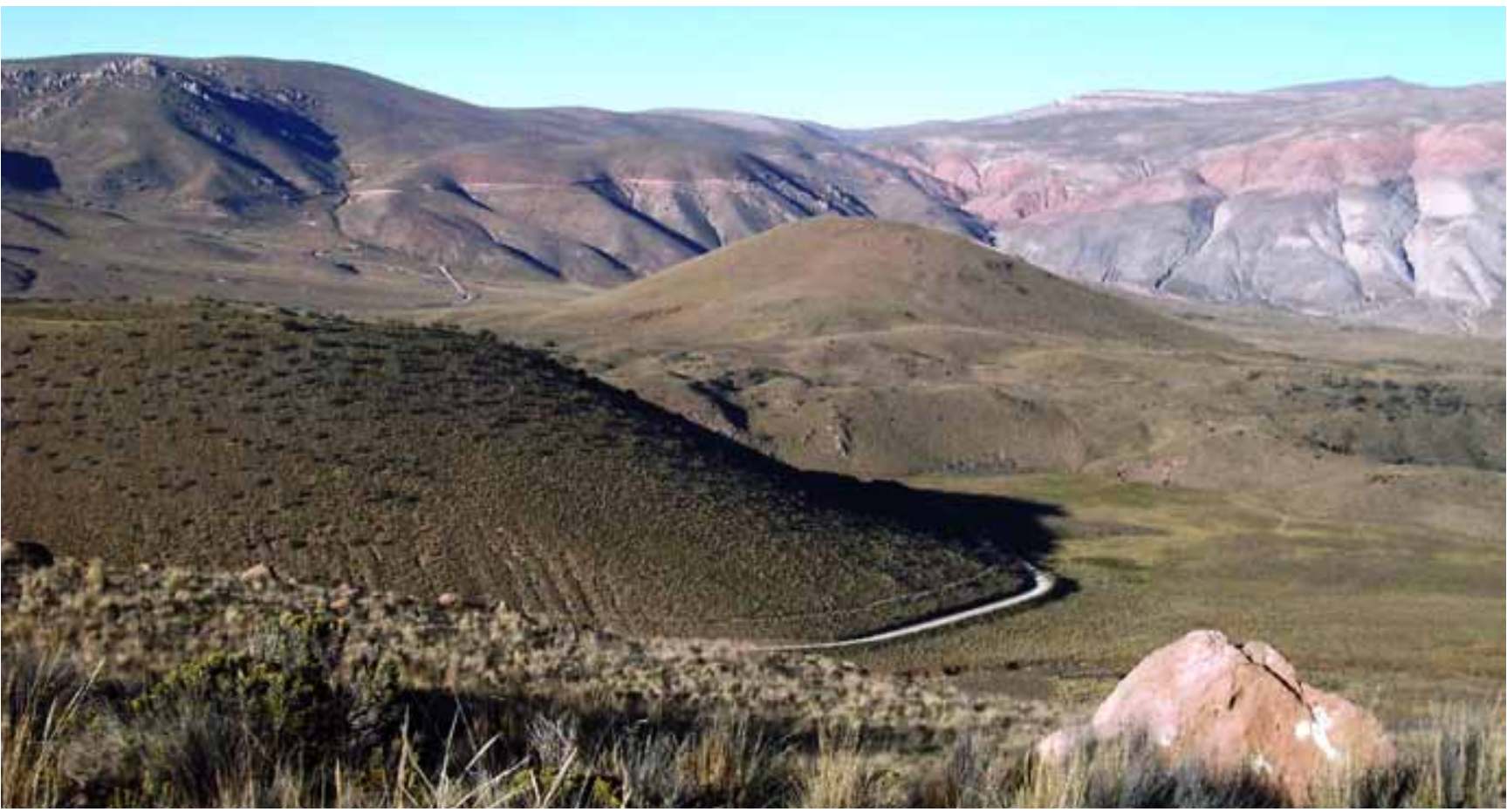

Fig. 11. View on Valley of Volcanoes, phot. B. Radwanek-Bąk • Dolina Wulkanów, fot. B. Radwanek-Bąk

are predominated by dark or dark-grey aphanitic varieties while porphyric lavas of andesite type occur more rarely (Delacour et al. 2002). Differentiated vegetation cover helps to discriminate the youngest plant-overgrown lava streams. The "moon-like" landscape of the Valley of the Volcanoes is another attraction due to unique visual assets.

Other interesting sites in the Valley of the Volcanoes, like Shanquillay waterfalls of the Andagua River and Chachas and Mamachocha lakes, can also be considered the geotourist attractions.

\section{Buildings}

The objects, which can be treated as geotourist attractions comprise also various buildings, including churches or their fragments built of stones. The church in Yanque is likely the most beautiful masterpiece of stonework in this region. It is built of tuffs and has the richly sculptured frontage as well as plentiful floral ornaments (Fig. 12). Other churches, which can be spotted even in the small towns (Chivay, Lari, Maca, Madrigal, Coporaque, Pinchollo, Cosnirhua, Tapay, Ayo, Andagua etc.), should be rather treated as objects of cultural heritage of this region. History of the majority of these churches is some centuries-long. They are austere and posses a few architectural details, nevertheless their unique elements and interesting interiors appeal especially to the foreigners. Even though the churches are usually built of tuffs (ignimbrites), the dimension stones cannot be admired as the walls are usually plastered and the original rock material and stony decorative elements are masked.

The briefly outlined geotourist objects of the Colca Canyon and its vicinity are only a small portion of the huge assortment. During the undertaken expedition several tens of abiotic environmental items under definition of the geotourist attraction have been inventorized. The majority of them are

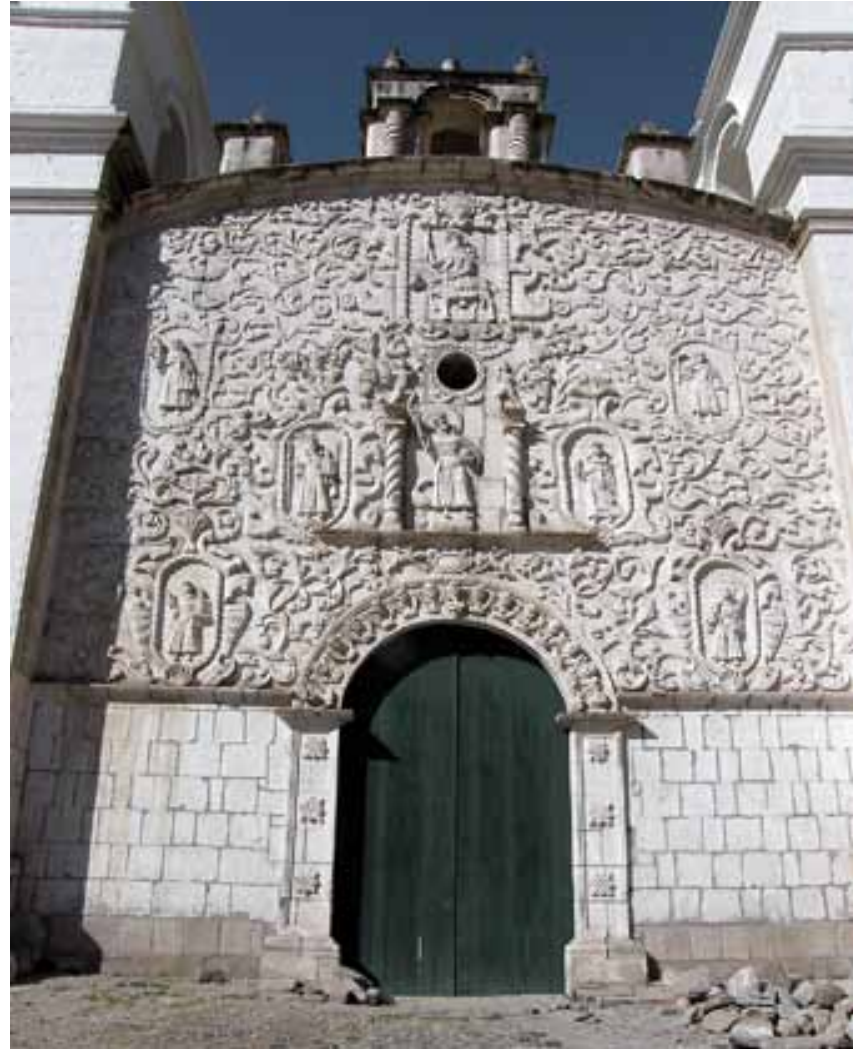

Fig. 12. A stone Immaculate Conception church in Yanque with the rich sculptured colonial baroque facade, phot. B. Radwanek-Bak • Kamienny kościół w Yanque $\mathrm{z}$ bogato zdobioną, rzeźbioną fasadą w stylu kolonialnego baroku, fot. B. Radwanek-Bąk

being significant educational-cognitive and landscape-visual assets. Others, like for example thermal water swimming pools, have recreational-resting values. The trip to the Colca Canyon floor is irresistible owing to unforgettable landscapevisual impressions and educational benefits. Moreover, during such trips the tourists can observe differentiated vegetation 
and climatic zoning, from high-mountain to tropical belts, related to changes in the altitude (Cykowska, Flakus, 2008).

The performed studies are only primary. The analysis of the collected archive materials, extent of the study area, diversity of geology and morphological forms as well as the performed field reconnaissance suggest that much more object could be assigned as geotourist attractions. This justifies the need for further studies. Apart from inventories, document- ing and valorisation of the objects in question, indispensable issues for promoting them as attractive to tourist interests comprise: appropriate and appealing descriptions, delineation of walking and trekking trails and estimation of associated development and maintenance costs. The tourist-addressed promotions to be undertaken have to be coupled with protection framework aiming at complex preserving of animate and inanimate nature of this unique world region.

\section{Streszczenie \\ Wybrane geotopy i obiekty geoturystyczne kanionu Colca i jego otoczenia (południowe Peru)}

\section{Barbara Radwanek-Bąk}

Dolina Rio Colca, a w szczególności jej fragment tworzący najgłębszy kanion świata to obszar o wybitnej georóżnorodności, wyjątkowych walorach krajobrazowym i bogatym dziedzictwie kulturowym całej okolicy. Dodatkowym elementem podnoszącym atrakcyjność tego obszaru jest możliwość obserwacji aktywnych procesów geologicznych. Dlatego też od kilkunastu już lat przyciąga on liczne rzesze turystów. Wielu z nich przyciąga też możliwość podziwiania skrzydlatych władców tej krainy - kondorów oraz chęć sprawdzenia swych możliwości i kondycji podczas wyprawy na dno kanionu.

Analogicznie do pojęcia bioróżnorodności, odnoszącego się do zmienności przyrody ożywionej, termin georóżnorodność oznacza zmienność i zróżnicowanie elementów abiotycznych (Nieto, 2001, Gray, 2004, Kozłowski, 2004, Kot, 2004, Panizza, Piacente, 2009). Dotyczy to w szczególności zróżnicowania: budowy geologicznej, inwentarza skalnego i gleb, struktur tektonicznych, morfologii terenu, rozwoju form erozyjnych, oraz wód. Co więcej, to właśnie georóżnorodność decyduje niejednokrotnie również o bioróżnorodności. Oba te komponenty w połączeniu $\mathrm{z}$ antropogenicznymi przekształceniami środowiska w zasadniczy sposób wpływają na zróżnicowanie, a w konsekwencji również na atrakcyjność krajobrazową terenu. Widzialnymi przejawami i miernikami georóżnorodności są geotopy - elementy przyrody nieożywionej, które niosą czytelną informację na temat rozwoju skorupy ziemskiej, procesów geologicznych lub życia na Ziemi (Bruschi, Cendrero, 2009). Zwane są one również geostanowiskami (stanowiskami dokumentacyjnymi). Zalicza się do nich:

- naturalne lub sztuczne odsłonięcia skał interesujące pod względem geologicznym tj. wychodnie skał, profile geologiczne, nagromadzenia skamieniałości, ciekawostki mineralogiczno-petrograficzne, struktury tektoniczne, sedymentacyjne itp.

- formy geomorfologiczne tj. różnorodne elementy rzeźby terenu: doliny, skałki, jaskinie, głazy narzutowe, wąwozy, wulkany itp.

- obiekty hydrogeologiczne: źródła, jeziora, gejzery.

Powinny one charakteryzować się walorami naukowopoznawczymi i edukacyjnymi oraz dostępnością umożliwia- jącą ich wykorzystanie jako obiektów obserwacji. Cechami pożądanymi jest ich atrakcyjność turystyczna i estetyczna.

Wiele geotopów może być uznanych jako atrakcje geoturystyczne, tj. takie, które oprócz wąskiego grana fachowców przyciągną szerszą rzeszę turystów. W szerszym kontekście atrakcjami geoturystycznymi mogą być również obiekty kultury materialnej związane z działalnością wydobywczą, a także specjalistyczne muzea, gromadzące zbiory okazów geologicznych lub zapoznające $\mathrm{z}$ historią rodzimego górnictwa itp.

Zbadanie potencjału geoturystycznego kanionu Colca i jego otoczenia stanowiło jeden $\mathrm{z}$ wyodrębnionych celów badawczych wypraw naukowych zorganizowanych w latach 2006 i 2008 przez pracowników naukowych krakowskiej AGH przy współudziale badaczy z innych placówek naukowo -badawczych w kraju.

Autorka składa podziękowania organizatorom wyprawy za włączenie jej do interdyscyplinarnego zespołu badawczego i umożliwienie przeprowadzenia własnych badań.

\section{Metody badań}

Podstawą oceny potencjału geoturystycznego badanego obszaru było przeprowadzenie inwentaryzacji atrakcji geoturystycznych. Punktem wyjścia była analiza różnorodnych materiałów źródłowych, w tym opracowania archiwalne, udostępnione przez przedstawicieli lokalnych władz. Przeprowadzono też szereg wywiadów z przedstawicielami miejscowych władz, biur turystycznych i rozmów z mieszkańcami. Uzyskane tą drogą informacje były następnie weryfikowane w terenie. Obszar badań obejmował dolinę Rio Colca od okolic miejscowości Sibayo, po rejon Huambo oraz tzw. Dolinę Wulkanów (Fig. 1) . Usytuowana ona jest poprzecznie w stosunku do osi doliny i Rio Colca, a płynące jej dnem rzeki Mamacocha i Ayo są dopływami Rio Colca., uchodząc doń w obrębie kanionu

Dokonano też wstępnej waloryzacji obiektów geoturystycznych w oparciu o opracowane wcześniej przez autorkę kryteria (Radwanek-Bąk, 2008). Wyróżniono następujące kryteria:

- walory naukowo-poznawcze

- walory krajobrazowo-widokowe

- walory architektoniczno-kulturowe

- walory rekreacyjno- wypoczynkowe

- dostępność.

Pierwsze $\mathrm{z}$ wymienionych mają decydujące znaczenie dla uznania obiektu jako geotop. Przy kwalifikacji geostanowisk jako atrakcji geoturystycznych należy wziąć pod uwage również pozostałe elementy, w tym w szczególności dostęp- 
ność, która w zasadniczy sposób wpływa na ilość turystów odwiedzających dany obiekt.

\section{Dolina Rio Colca}

Rzeka Colca bierze swój początek na zboczach szczytu Yanasalla (4886 m npm) górującego nad wysokogórską równiną, będącą południową częścią Altiplano. Początkowo płynie bezludnymi obszarami, rozcinając młode osady utworzone z wietrzejących skał wulkanicznych, głównie tufów oraz law andezytowych, które związane są z mioceńskoplioceńskim wulkanizmem. Starsze, mioceńskie skały wulkaniczne otaczające dolinę grupują kilka formacji tworzących łącznie tzw. grupę Tacza (Paulo, 2008). W pobliżu miejscowości Callalli można obserwować należące do niej pięknie wykształcone formacje ignimbrytowe, o charakterystycznym ciosie słupowym (Fig. 2). Skała ta dzięki dobrym własnościom termicznym i łatwej obróbce stanowi powszechnie używany na terenie całej prowincji Arequipa materiał budowlany.

Najważniejszą miejscowością w tej części doliny jest Chivay, lokalne centrum administracyjne i turystyczne. Na odcinku między Chivay na wschodzie, a Huambo na zachodzie dolinę otaczają z obu stron wysokie stratowulkany: Mismi (5597 m npm.), Bomboya (5 $200 \mathrm{~m}$ npm), Coropuna (6 $425 \mathrm{~m}$ npm), a od południa Hualca-Hualca (6 025 m npm ), Sabancaya (5976 m npm.) i Ampato (6314 m npm.). Ich aktywność trwająca od pliocenu, zaznaczyła się obecnością miąższych utworów wulkanicznych (Fidel i in., 1997). Są to lawy andezytowe, dacytowe, dacytowo-andazytowe, oraz tufy, brekcje andezytowe lub zlepieńce tworzące kilka różnowiekowych kompleksów, budujących wspólnie tzw. Grupę Barroso (Caldas, 1993). Począwszy od Chivay charakter doliny zmienia się. Rzeka wcinając się w miąższe kompleksy skalne utworzyła kilkupoziomowy system tarasów, których pierwotne ukształtowanie zostało znacznie zmienione wskutek działalności człowieka. Ze względu na korzystne warunki klimatyczne i dobre gleby, powstałe na podłożu skał wulkanicznych, ta część doliny była zasiedlona od czasów preinkaskich i intensywnie użytkowana rolniczo (Wernke, 2003).

Omawiany fragment doliny można uznać za atrakcje geoturystyczną, dającą możliwość zaznajomienia się z głównymi rysami budowy geologicznej i inwentarzem skalnym doliny, a nade wszystko z jej morfologią zmienioną w wyniku wielowiekowych przekształceń antropogenicznych (Fig. 3). Szczególne możliwości obserwacji doliny dają rozmieszczone nad doliną punkty widokowe.

Znajduje się tu szereg odrębnych geotopów, będących zarazem atrakcjmi geoturystycznymi dużej klasy. Są to w szczególności miejsca, w których można bezpośrednio obserwować aktywne zjawiska geologiczne:

- strefa uskokowa Maca-Madrigal (Fig. 4),

- czynne osuwisko koło miejscowości Madrigal wraz z kilkoma jeziorkami osuwiskowymi (Fig. 5).

Oprócz walorów poznawczych posiadają one znaczne walory krajobrazowe.

Odrębny typ atrakcji geoturystycznych związany jest z występowaniem na tym terenie źródeł wód termalnych. Są one liczne, choć zazwyczaj o małej wydajności. Tylko niewielka ich ilość jest ujmowana, a do najważniejszych ujęć należą : La Calera w Chivay (Fig. 6) i źródła w miejscowości Yanque, gdzie zbudowano baseny rekreacyjne.

Atrakcją geoturystyczną o charakterze mineralogicznopetrograficznym jest wystąpienie diatomitów w Maca (Fig. 7). Obecność tej skały, pochodzenia organogenicznego, zbudowanej z fragmentów szkieletów okrzemek świadczy o istnieniu na tym terenie słodkowodnego zbiornika wodnego. Koncentracji okrzemek sprzyjała zapewne niska temperatura wód oraz duża zawartość rozpuszczonej krzemionki, której źródłem były zapewne powszechne tu utwory pochodzenia wulkanicznego.

O obecności zbiorników słodkowodnych w tym rejonie świadczy też obecność liczynch odsłonięć osadów jeziornych, nieraz o znacznej miąższości (Fig. 8). Są to osady pylaste, drobnolaminowane. Niekiedy wykazują one warstwowanie przekątne. W obrębie serii limnicznej występują też warstwy gruboklastycznych aluwiów. Obecność serii osadów limnicznych związana jest najprawdopodobniej z dużym wybuchem wulkanu Mismi, który miał miejsce na przełomie trzeciorzędu. Wychodnie tych osadów można zaliczyć do atrakcji o charakterze sedymentologicznym o wyjątkowych walorach poznawczych. Ich obserwacja i korelacja oraz ustalenie wieku tych osadów może w istotny sposób przyczynić się do uściślenia geologicznej historii doliny, a w szczególności wieku powstania kanionu Colca.

\section{Kanion Colca \\ na odcinku Pinchollo-Canco}

Kanion Colca rozpoczyna się w okolicach miejscowości Pinchollo. Jego długość wynosi około $120 \mathrm{~km}$. W najgłębszym miejscu osiąga głębokość $3232 \mathrm{~m}$. Jego dostępność jest ograniczona. Turystycznie dostępny jest w zasadzie jedynie fragment kanionu na odcinku od Pinchollo do Canco, gdzie jego głębokość (od poziomu doliny) sięga około $1800 \mathrm{~m}$. Istnieje tu kilka ścieżek zejściowych z miejscowości Pinchollo, Cabanaconde i Huambo. Brak wody oraz konieczność pokonania dużych odległości i deniwelacji terenu są największymi trudnościami, na które napotykają turyści chcący odwiedzić dno kanionu. Dodatkowymi utrudnieniami są strome i kruche skały budujące jego ściany.

W najbardziej odwiedzanym przez turystów rejonie w pobliżu miejscowości Cabanaconde zbocza kanionu zbudowane są głównie z miąższych kompleksów skał wulkanicznych reprezentujących formacje grup Tacaza i Barroso (Fig. 9). W dolnych częściach i dnie kanionu odsłaniają się starsze skały osadowe tzw. grupy Yura, wieku jurajsko (oksford, kimeryd) - dolnokredowego (walanżyn). Generalnie budują je osady piaskowcowo-łupkowe o barwie czarno-szarej, niekiedy z przeławiceniami lutytów. Piaskowce są zwięzłe, o spoiwie węglanowym lub krzemionkowym, lokalnie kwarcytowe (Caldas, 1993). Na odcinku między Pinchollo a Soro, skały grupy Yura odsłaniają się tylko w dnie kanionu, zaś w rejonie Huambo oraz w dolnym biegu dopływu Rio Mamacocha, która odwadnia Dolinę Wulkanów, wpadając do Rio Colca - budują niemal całe stoki kanionu. (Fig. 10). Profile zboczy kanionu, odsłonięcia formacji skalnych i struktur fałdowych, oraz sama morfologia kanionu są atrakcjami turystycznymi o wybitnych walorach edukacyjno-poznawczych 
i krajobrazowo-widokowych. Można obserwować je podczas wycieczek do kanionu, a także z kilku punktów widokowych, spośród których najsławniejszym jest Cruz del Condor miejsce to znane głównie jako punkt obserwacji wylatujących codziennie rano z dna kanionu kondorów.

\section{Dolina Wulkanów}

Dolina Wulkanów o długości około $60 \mathrm{~km}$, jest boczną doliną w stosunku do doliny Rio Colca. Pod względem geologicznym jest to rów tektoniczny wypełniony neogeńskimi tufami, na których leżą bardzo młode, plejstoceńskie, lawy formacji Andahua (Gałaś, Paulo, 2005).

Znajduje się tu kilkadziesiąt karłowatych wulkanów, tworzących regularne stożki (Fig. 11). W materiałach źródłowych podawana jest różna ich ilość - od 31 do 85 (Krzak, 2005). Wizyta w Dolinie Wulkanów daje możliwość obserwacji niemal współczesnych efektów działalności wulkanicznej w postaci wulkanów oraz potoków lawowych. Wśród law przeważają czarne lub ciemnoszare lawy afanitowe typu bazaltowego. Rzadziej występują lawy porfirowe typu andezytowego (Delacour i in. 2002). Zróżnicowanie pokrycia potoków lawowych roślinnością pozwala łatwo zidentyfikować najmłodsze spośród nich. „Księżycowy” krajobraz Doliny Wulkanów stanowi również atrakcję ze względu na unikatowe walory widokowe.

W Dolinie Wulkanów znajdują się również inne interesujące obiekty, które można zaliczyć do atrakcji geoturystycznych. Są nimi wodospady Shanquillay na Rio Andagua oraz jeziora Chachas i Mamachocha.

\section{Budowle}

Za obiekty, które mogą mieć znaczenie jako atrakcje geoturystyczne można uznać również różnorodne budowle, w tym kamienne kościoły lub ich fragmenty, w których wy- eksponowany jest materiał skalny, z którego zostały zbudowane. Najpiękniejszym bodaj przykładem sztuki kamieniarskiej na tym terenie jest kościół w miejscowości Yanque wykonany z tufów (ignimbrytów), z bogato rzeźbioną kamienną fasadą i elementami dekoracyjnymi w postaci motywów kwiatowych (Fig. 12). Inne kościoły, które znajdują się niemal w każdej, nawet małej miejscowości (Chivay, Lari, Maca, Madrigal, Coporaque, Pinchollo, Cosnirhua, Tapay, Ayo, Andagua i in.) należy traktować głównie obiektami dziedzictwa kulturowego tego terenu. Większość z nich to obiekty o kilkusetletniej historii, surowe i skromne w detale architektoniczne, ale wyróżniające się charakterystycznymi elementami budowli i ciekawym zwłaszcza dla obcokrajowców wystrojem wewnętrznym. Ich ściany są często otynkowane, co utrudnia obserwację ich tworzywa skalnego (ignimbryty) i kamiennych elementów zdobniczych.

Przedstawione krótko obiekty geoturystyczne kanionu Colca i jego okolic to jedynie niewielka część $\mathrm{z}$ bogatego ich zbioru. W trakcie wyprawy zinwentaryzowano bowiem kilkadziesiąt obiektów przyrody nieożywionej spełniających kryteria atrakcji geoturystycznej. Większość z nich posiada wysokie walory edukacyjno-poznawcze, a równocześnie duże walory krajobrazowo-widokowe. Niektóre, jak np. baseny wód termalnych, mają znaczne walory rekreacyjno-wypoczynkowe. Wybitnych wrażeń krajobrazowo-widokowych oraz poznawczych dostarcza wyprawa na dno kanionu. W jej trakcie turyści mogą obserwować również zróżnicowanie roślinności i warunków klimatycznych, które zmieniają się wraz z deniwelacją terenu - od wysokogórskich po niemal tropikalne (Cykowska, Flakus, 2008).

Bogactwo i różnorodność przyrody nieożywionej oraz piękno krajobrazów Doliny i Kanionu Rio Colca, w połączeniu z ciekawą florą i fauną, wielowiekową historią i kulturą oraz wciąż żywym folklorem, sprawiają,że jest to jedno $\mathrm{z}$ niepowtarzalnych miejsc na Ziemi, które bezwzględnie należy zachować i chronić.

\section{References (Literatura)}

Bębenek S., 2006. Peru. Wybrane obiekty geoturystyczne w rejonie kanionu Colca. Geoturystyka, 2(5):53-62.

Brushi V.M. , Cendrero A., 2009. Direct and parametric methods for the assessment of geosites and geomorphosites. in: Geomorphosites. (ed. E. Reynard, P. Coratza, G Regolini-Bissig). Verlag Dr. F. Pfeil. Munchen. Caldas Vidal J., 1993. Geologia de los cuadrangulos de Huambo y Orcopampa. Bol. Com.Carta Geol. Nacional.46.Lima.

Chavez O.A., Chavez P., Malaga J.L., Miranda M., Soldan E., 2003. Curso taller "Actualizacion y certification de calidad para guias de ArequipaValle Colca”. t. II. AECI. Arequipa. Peru.

Cykowska B., Flakus A., 2008. Flora mszaków i porostów Kanionu Colca (Peru) - badania rekonesansowe. Zeszyty Naukowe AGH. Geologia, 34, 193-205, Kraków.

Delacour A., Paquereau P., Gerbe M.C., Thourlet J.C., Wórner G., 2002. Quaternary minor volcanic centres in southern Peru: volcanology, petrology and geochemistry. $5^{\text {th }}$ ISAG, 175-179. Touluse.

Fidel L.S., Morche W., Nunez J.S.,1997. Inventario de volcanes del Peru. INGEMMET. Bol. 15. Lima.

Gałaś A., Paulo A., 2005. Karłowate wulkany formacji Andahua w południowym Peru. Przeglad Geologiczny, 53:4, 320-326.

Gray M., 2004 - Geodiversity. Valuing and conserving abiotic nature. Chichester, Wiley.

Kalicki T., Kukulak J., 2008. Czwartorzędowa ewolucja Doliny Kanionu Colca - raport z badań geomorfologicznych wykonanych w 2006 r. Zeszyty Naukowe AGH. Geologia, 34:55-83, Kraków.
Kot R., 2006. Georóżnorodność - problem jej oceny i zastosowania w ochronie i kształtowaniu środowiska na przykładzie fordońskiego odcinka doliny Dolnej Wisły i jej otoczenia. Studia Societas Scientiarium, XI. No 2.Uniwersytet M. Kopernika, Toruń.

Kozłowski S., 2004. The content and scope of Geodiversity. Przeglad Geologiczny, 52:833-839.

Krzak M.,2005. Ruch turystyczny w rejonie Arequipy i możliwości jego rozwoju w Dolinie Wulkanów (prowincja Castilla) w południowym Peru. Geoturystyka, 2:3-22.

Nieto L. M., 2001. Geodiversidad: propuesta de una definicion integratora. Bol.Geologico y Minero. 112, 2:3-12.

Panizza M., Piacente S, 2009. Curtural geomorphology and deodiversity. In: : Geomorphosites.(ed. E. Reynard, P. Coratza, G Regolini-Bissig). Verlag Dr. F. Pfeil. Munchen.

Paulo A., 2008. Zarys budowy geologicznej Kordyliery Zachodniej południowego Peru. Zeszyty Naukowe AGH. Geologia,34:35-54.

Radwanek-Bąk B., 2008. Atrakcje geoturystyczne kanionu Colca i jego otoczenia. Zeszyty Naukowe AGH. Geologia. 34: 173-193.

Serrano E., Ruiz-Flano P., 2009 - Geomorphosites and geodiversity. In: Geomorphosites.(ed. E. Reynard, P. Coratza, G. Regolini-Bissig). Verlag Dr. F. Pfeil. Munchen.

Słomka T., Kicińska-Świderska A., 2004 - Geoturystyka - podstawowe pojęcia. Geoturystyka. 1:5-7.

Wernke S., 2003. An Archaro-history of Andean Community and Landscape. The late prehispanic and early colonial Colca Valley Peru. Disertation University of Wisconsin-Madison, 1-443. 